\title{
Nuclear industry goes public
}

RECENT years have demonstrated that, in Britain at least, if any of the components of the unholy government-industry-trades union triumvirate start making signs that they are taking a view on a matter, that matter is fast becoming an important issue. So when the Financial Times organises a conference on nuclear power-or, more precisely, "Nuclear Power and the Public Interest: the Implication for Business"-it's a fair bet that energy, and specifically nuclear energy, is an item on the UK public agenda.

Evidence for this, of course, was around before last week's conference. Mr Benn, the UK Energy Minister, saw to that (if the world's energy problems hadn't already done so) with his recent energy talk-in and his public debate six months ago on the reprocessing of nuclear fuel. But with evidence a-plenty offered at the conference to show that the future use of nuclear power in industrialised countries could not be escaped, short of a return to an agragrian economy or a drastic fall in living standards, the nuclear issue seemed more confined than usual.

Still, the problem of the long lead-times attaching to nuclear operations helps to make nuclear power the live issue it now is. The likelihood of a UK "energy gap" in the 1990s is disputed in some quarters and subject to uncertainties, but if it is to appear, and sooner rather than later, it means decisions on nuclear programmes are needed now, with a correspondingly bigger margin of doubt on all fronts. And where there are decisions to be made, there too will the issues be created.

Hardly surprising, then, that people in the nuclear industry should be talking, a little over-dramatically, of its very survival over the period of energy surplus. Hardly surprising, either, that the Department of Energy, which doesn't yet doubt that the nuclear option must at least be retained, should become the object of attention for those seeking to influence the decisions which the "public" character of the nuclear issue now foreshadows.

The critical decision, on whether to go ahead with a demonstration fast breeder reactor (FBR), is expected sometime in the autumn. Unexpected, if heavily qualified, support for a demonstration FBR came at the conference from the Chairman of the Royal Commission on Environmental Pollution, Sir Brian Flowers (now looking at the effect of nuclear power), and from Leslie Grainger of the National Coal Board. Great uncertainty was again expressed, however, about the fate of the Steam Generating Heavy Water Reactor (SGHWR).

On less specific though no less important aspects of nuclear power, grave doubts were expressed, and brave responses offered: about the disposal of radioactive wastes after reprocessing (confidence was expressed about glassification techniques, and about burial in deep holes or under the ocean bed); about health and safety in the nuclear industry (favourable comparisons were drawn with other industries, and especially coal); about proliferation through international nuclear trade (to stop this, claimed one businessman, would be to encourage countries to develop their own technology over a longer period); about the chances of a nuclear accident (all necessary precautions were taken) and nuclear terrorism (the chances of a successful action were minimal); and about the economic facts of nuclear power (which, like all economic "facts", it became apparent, translate only as interpretations). To emerge with the right questions seemed more important in the end than having pat answers.

This was less true of other controversial questions which were broached about the nuclear issue. What should the role of the state be in the nuclear industry, if not in encouraging private enterprise in its task? How was a stream of steady orders to be secured to tide the UK industry over the coming years, if not by breaking into the export business with a marketable reactor? How was any progress to be made without international cooperation, specifically with Britain's European partners? Disappointingly, these questions, for most delegates, contained their own answers.

Not that the unique long term aspects of nuclear power ("making decisions for future generations") weren't acknowledged. But views on nuclear power for the most part revealed differences of detail rather than principle. Although the differences weren't insubstantial for that, there was unfortunately no real voice posing the obvious question-namely, who or what is the anti-nuclear lobby in Britain? (Everyone knows the answer to the analogous American question.)

This latest conference on the subject indicated that the British nuclear industry is finding it necessary to change its public position by actually adopting one. But if nuclear power is really on the public agenda, there are still more fundamental issues to be discussed, if only to be confirmed as resolved. 